\title{
The base colour of fruit as an indicator of optimum harvest date for two apple cultivars (Malus domestica Borkh.)
}

\author{
Department of Pomology \\ Poznan University of Life Sciences \\ Dąbrowskiego 156, 60-594 Poznań, Poland
}

\begin{abstract}
The CIE L* $\mathrm{a}^{*} \mathrm{~b}^{*}$ colour system is used to evaluate food colours. Its advantage is that the base skin colour in apples can be measured on the same fruit before and on the optimum harvest date. The aim of the research conducted between 2002 and 2006 was to evaluate a quick and non-destructive method of determining the optimum harvest date of apples intended for long storage based on the changes observed in the base skin colour. Another important research aspect was to compare this method with other methods or indicators used to determine the harvest date. The colour measurement was conducted on two apple cultivars, Šampion and Royal Gala, with the aim of, amongst other factors, establishing a standard for each that could be used in practice in fruit production. From amongst the evaluated colour indicators $\mathrm{L}^{*}, \mathrm{a}^{*}, \mathrm{~b}^{*}, \mathrm{Hue}_{\mathrm{ab}}$ angle and chroma, changes in the base colour were best illustrated by the $\mathrm{a}^{*}$ coordinate value and $\mathrm{Hue}_{\mathrm{ab}}$ angle value. Based on the evaluation of the quality of fruits after storage, it can be stated that the fruits had the best quality when the $\mathrm{a}^{*}$ coordinate during harvest ranged between -7 and -8 for 'Šampion' and between -3 and -5 for 'Royal Gala'. The Hue ${ }_{a b}$ angle assumed a value between 100 and 101 for 'Šampion' and between 96 and 99 for 'Royal Gala' during the optimum harvest date. Therefore, the $\mathrm{a}^{*}$ coordinate and the $\mathrm{Hue}_{\mathrm{ab}}$ angle can be used to indicate harvest maturity.
\end{abstract}

Key words: acidity, CIE L* a*b*, firmness, fruit ripening, Hue ${ }_{a b}$ angle, storability, TSS

\section{Abbreviations:}

CIE L* $a^{*} b^{*}-L^{*}, a^{*}, b^{*}$ colour space; OHD - optimum harvest date; TA - titratable acidity; TSS - total soluble solids

\section{INTRODUCTION}

The harvest date is crucial for the storability of autumn and winter apple cultivars intended for long storage. Only apples picked at the optimum maturity stage are suitable for storage over three months (autumn cultivars) and over five months (winter cultivars) because of better storage potential and organoleptic quality. Fruits harvested at an unripe stage are more prone to shrivelling (Łysiak and Kurlus 2000), internal breakdown and are of inferior quality when ripe. Overly mature fruits are likely to become soft and mealy and have insipid flavour after a short storage time (Kays 1991). Base colour is correlated with maturity in most fruits (Kays 1991, Kader 1999). For some fruits, there are already colour standards for determining

\footnotetext{
*Corresponding author.

Tel.: +48 6184879 46; fax: +48 6184879 99;

e-mail: glysiak@up.poznan.pl (G. Łysiak).
} 
the optimum harvest date (OHD). In the United States, a colour pattern for evaluating the maturity for peaches (Delwiche and Baumgartner 1983, Meredith et al. 1989), and nectarines (Luchsinger and Walsh 1998) was developed. Some research has been conducted in this area in Australia with mango (Kang et al. 2008), in Spain with table grapes (Carreño et al. 1995) and peaches (Ferrer et al. 2005) and in Portugal with sweet cherries (Gonçalves et al. 2007). In many fruits, changes in colour involve the loss of chlorophyll, the synthesis of new pigments such as carotenoids and/or anthocyanins, and the unmasking of other pigments that were previously formed during the development of the fruit (Ferrer et al. 2005). Another aspect is to make a fast, non-destructive measurement because traditional, chemical pigment concentration analysis is tedious and destructive. Still another advantage of colour measurement is that it can be taken several times during a given period on the same fruit. The CIE $L^{*} a^{*} b^{*}$ colour system (Commision Internationale de l'Eclairge) is extensively used to evaluate food colours (Anonim 1986). The objective of this study was to measure the apple base colour as a function of maturity and to examine its relationship with other maturity indices. Colours were measured along coordinates sufficient for later specification of colour reference shades.

\section{MATERIAL AND METHODS}

The research was conducted in the cold storage facility and laboratory of the Department of Pomology of the Poznan University of Life Sciences between 1999 and 2006 and was designed to determine and evaluate the colour changes of all cultivars. Fruits were picked from trees of the 'Šampion' and 'Royal Gala' cultivars planted in 1992 on M.26 rootstock in single $4 \times 2 \mathrm{~m}$ rows, the trees having a wide spindle shape. The orchard was protected and maintained in line with the recommendations for commercial orchards.

\section{Sampling}

In 2002-2006, fruits were collected every 4-5 days starting some weeks before the estimated OHD. The sample size was 20 fruits picked from a minimum of 10 trees, from 140 to $160 \mathrm{~cm}$ high, from the outside part of the tree, from the same east-southern side. Fruits over or under size, infected by pests or diseases were rejected. The fruits should represent the stage of maturity (in size and colour) of those fruits that will be harvested during the main harvest. In most years, fruits intended for cold storage were also collected on the last four sampling dates. The harvest was conducted according to the rules applicable to the picking samples, but the size of a single sample intended for storage was considerably larger and amounted to four boxes of $10 \mathrm{~kg}$ each box. The approximate OHD was determined mainly on the basis of starch index measurements and Streif index calculations, whereas the exact OHD was determined after storage based on the results of quality and quantity research described in the methodology part below.

\section{Measurement}

The fruit maturity and ripeness at harvest were evaluated according to well-known standard methods: firmness: penetrometer (probe $-8 \mathrm{~mm}$ depth, $11 \mathrm{~mm}$ in diameter), two opposite sides of the fruit, in kgf; refractometer value (TSS) in $\%$; starch disintegration according to a 10-point scale, where 1 means "no conversion" and 10 means "totally converted" (Brookfield et al. 1997), titratable acidity (TA): titration with $0.1 \mathrm{~N} \mathrm{NaOH}$ to $\mathrm{pH} 8.1$ and expressed as mval/100 $\mathrm{mL}$ (PN90-A-75101/04).

\section{Storage condition and evaluation of storability}

Fruits were stored in a cold storage room at $1-2^{\circ} \mathrm{C}$ and $\mathrm{RH}$ of around $90 \%$ for three months ('Šampion') and for five months ('Royal Gala'). The schedule of all measurements is shown in Table 1. The storability of apples was evaluated after the same number of days of storage respective to their harvest date. The evaluation of storage efficiency was based on the judgment and on measurements. The judgment was made using sensory tests, incidence of diseases and disorders, fruit mass loss and internal quality criteria (firmness, TSS, TA). Each criterion was scored separately for each date of harvest. The scores were given according to the following rules:

1. Loss of fruit mass was measured in each stored box. Ten fruits were numbered and weighed with the accuracy of $0.1 \mathrm{~g}$ before and after storage. Scores were given according to an analysis of variance between the harvest dates. If there were no significant differences, each sample received 1 point. If the analysis showed a significant difference, a sample could receive 1, 2 or 3 points, with samples with the greatest loss receiving the lowest score.

2. Incidence of disorders and diseases was scored separately according to the analysis of variance. As in the previous case, a sample 
Table 1. Fruit collection days and storage length

\begin{tabular}{lcccccccccc}
\hline \multirow{2}{*}{ No. of measurement } & \multicolumn{1}{c}{ Sampion } \\
\cline { 2 - 12 } & 2002 & 2003 & 2004 & 2005 & 2006 & 2002 & 2003 & 2004 & 2005 & 2006 \\
\hline 1 & 22.08 & 9.09 & 8.09 & 7.09 & 27.08 & 23.08 & 22.08 & 28.08 & 25.08 & 23.08 \\
2 & 26.08 & 13.09 & 13.09 & 12.09 & 31.08 & 27.08 & 27.08 & 2.09 & 29.08 & 28.08 \\
3 & 31.08 & $\underline{17.09^{*}}$ & 18.09 & $\underline{16.09}$ & 5.09 & 31.08 & 1.09 & 6.09 & 02.09 & 02.09 \\
4 & $\underline{5.09}$ & $\underline{\underline{21.09^{* *}}}$ & $\underline{\underline{23.09}}$ & $\underline{21.09}$ & $\underline{15.09}$ & 5.09 & $\underline{5.09}$ & $\underline{11.09}$ & 05.09 & $\underline{07.09}$ \\
5 & $\underline{10.09}$ & $\underline{25.09}$ & $\underline{\underline{28.09}}$ & $\underline{\underline{26.09}}$ & $\underline{20.09}$ & $\underline{9.09}$ & $\underline{10.09}$ & $\underline{16.09}$ & $\underline{10.09}$ & $\underline{11.09}$ \\
6 & $\underline{14.09}$ & $\underline{30.09}$ & $\underline{3.10}$ & $\underline{30.09}$ & $\underline{25.09}$ & $\underline{13.09}$ & $\underline{15.09}$ & $\underline{20.09}$ & $\underline{15.09}$ & $\underline{16.09}$ \\
7 & $\underline{19.09}$ & 3.10 & $\underline{8.10}$ & 5.10 & $\underline{30.09}$ & $\underline{18.09}$ & $\underline{19.09}$ & $\underline{25.09}$ & $\underline{19.09}$ & $\underline{21.09}$ \\
8 & 24.09 & & & & 1.10 & $\underline{23.09}$ & 24.09 & 30.09 & $\underline{23.09}$ & \\
\hline End of storage & $06 \mathrm{Jan}$ & $12 \mathrm{Jan}$ & $14 \mathrm{Jan}$ & $16 \mathrm{Jan}$ & $15 \mathrm{Jan}$ & $20 \mathrm{Mar}$ & $23 \mathrm{Feb}$ & $02 \mathrm{Mar}$ & $27 \mathrm{Feb}$ & $23 \mathrm{Feb}$ \\
& 2003 & 2004 & 2005 & 2006 & 2007 & 2002 & 2004 & 2005 & 2006 & 2007 \\
\hline Storage period (days) & 122 & 118 & 114 & 121 & 121 & 163 & 171 & 174 & 170 & 169 \\
\hline
\end{tabular}

*Underlined dates present dates of harvesting sample for storage

**Double underlined dates present OHD based on evaluation after storage

could receive 1,2 or 3 points. If the percentage of non-healthy fruits was higher than $10 \%$ for disorders or diseases, respectively, the group sample received 1 point independent of the analysis of variance results. If the value was lower than 10 and the statistical analysis showed differences, the highest score (3 points) was given to the sample with the significantly lowest number of rotten fruits or fruits with disorders.

Firmness of 'Šampion' apples was scored according to the following point scale: 0 - below $4.0 \mathrm{kgf} ; 0.5-4.01-4.5 ; 1.0-$ $4.51-5.0 ; 2.0$ - 5.01-5.50; 3.0 - over 5.5 kgf. Due to the naturally higher firmness of 'Royal Gala', the kgf values on the scale were increased by 1.0 when scoring its firmness. The point scale was developed independently based on the research by Konopacka et al. (2003), which examined the relationship between texture attributes and consumers' perception and found that the minimum hardiness preferences for three examined cultivars were between 4.0 and $5.0 \mathrm{kgf}$.

3. TSS and TA were scored separately according to the same rules as mass loss (scores 1-3) and based on the analysis of variance. If TSS for 'Šampion' was below $11.5 \%$ and below $10.5 \%$ for 'Royal Gala', and if TA for 'Šampion' was below 0.25 and for below 0.2 'Royal Gala', all samples received a 1 for each criterion, independent of the analysis result.
4. Sensory tests were carried out by 3-5 professional judges according to the overall acceptance on the market along the following scale: 0 - no acceptance on market, 1 - poor acceptance, 2 - good, 3 - excellent. The average judgment was rounded to 0.5 points.

\section{Base colour evaluation}

The apple surface colour was measured with a handheld tristimulus reflectance colorimeter (Minolta CR-100, Minolta Corp., Ramsey, NJ, USA). Four replicates of 20 apples were used for each harvest date. The colour was recorded using a CIE L* $a^{*}$ $b^{*}$ uniform colour space (-Lab), where $\mathrm{L}^{*}$ indicates lightness, $a^{*}$ indicates chromaticity on a green (-) to red $(+)$ axis, and $b^{*}$ indicates chromaticity on a blue (-) to yellow $(+)$ axis. The numerical values of $a^{*}$ and $b^{*}$ were converted into Hue ${ }_{a b}$ angle $\left(\mathrm{H}^{\circ}=\right.$ $\left.\tan ^{-1} \mathrm{~b}^{*} / \mathrm{a}^{*}\right)$ and chroma [Chroma $=\left(\mathrm{a}^{* 2}+\mathrm{b}^{* 2}\right)^{1 / 2}$ ] (Francis 1980). The $\mathrm{L}^{*}$ value is a useful indicator of darkening during ripening on the tree and during storage, resulting from either oxidative browning reactions or increasing pigment concentrations. The $\mathrm{a}^{*}$ value is a measure of greenness, and is highly correlated with colour changes of apple flesh (Goupy et al. 1995). The $\mathrm{H}^{\circ}\left(\mathrm{Hue}_{\mathrm{ab}}\right)$ is an angle in a colour wheel of $360^{\circ}$, with $0^{\circ}, 90^{\circ}, 180^{\circ}$ and $270^{\circ}$ representing the Hues ab red-purple and yellow, respectively, while chroma is the intensity or purity of the Hue ${ }_{a b}$. The Hue ${ }_{a b}$ angle value was calculated taking into account the recommendations given by McLellan et al. (1995). The results were processed statistically using the analysis of variance. The differences between the average values were 
evaluated using the Duncan test with the assumed significance level of $\mathrm{p}=0.05$.

\section{RESULTS}

The optimum harvest dates for 'Šampion', determined on the basis of the storage results, were between 14 and 26 September and between 10 and 25 September for 'Royal Gala' (Tab. 1). Despite the differences in the physical and chemical properties of 'Šampion' and 'Royal Gala', the assessment of all parameters after storage allowed for a determination of the optimal harvest date (Fig. 1). Additionally, the evaluation of the fruit quality showed that 'Royal Gala' apples were less often infected with fungal diseases and physiological disorders and were characterised by significantly higher firmness and lower acidity. The firmness of 'Šampion' fruits was low, and, except in 2002, was a parameter which differed depending on the harvest date.
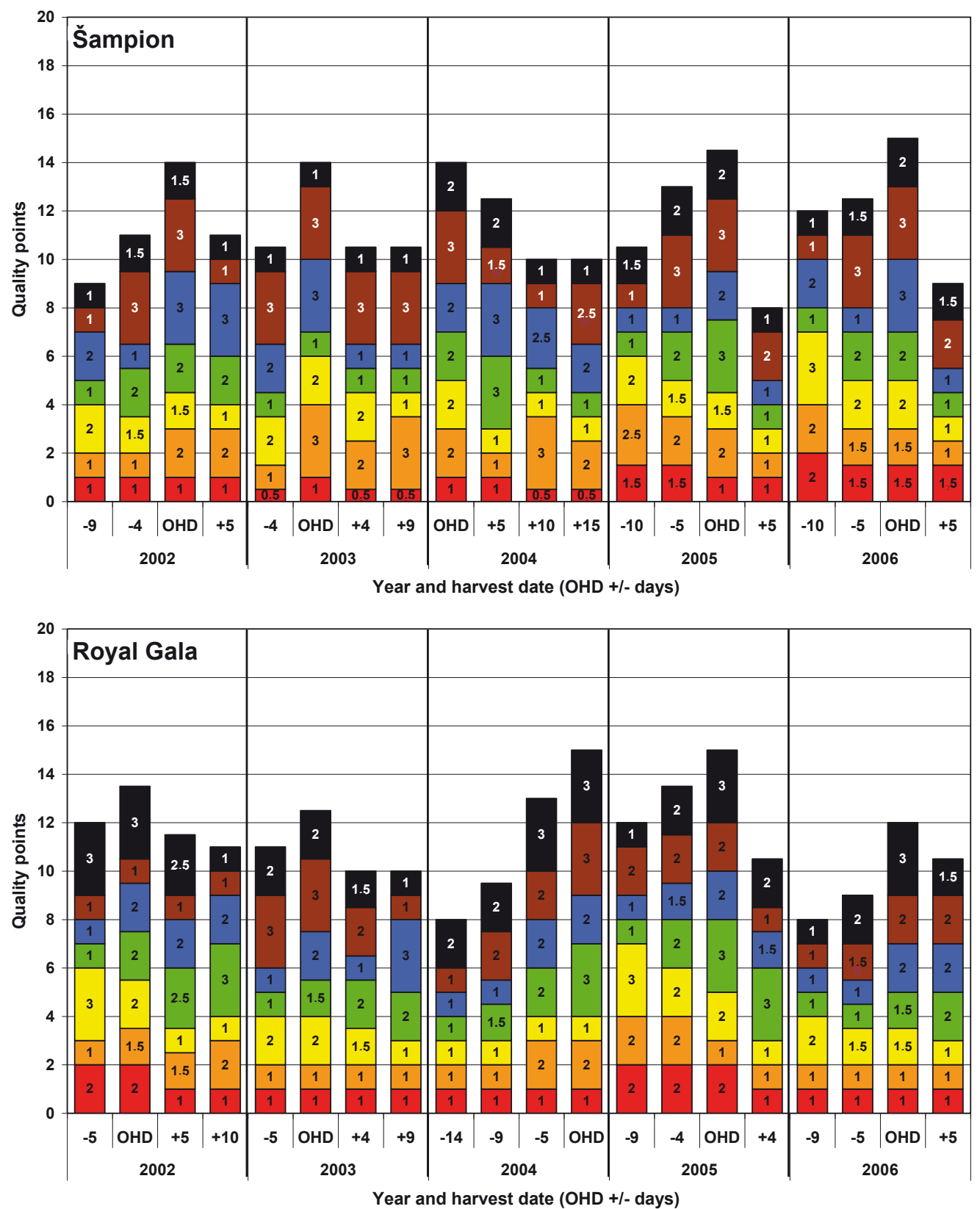

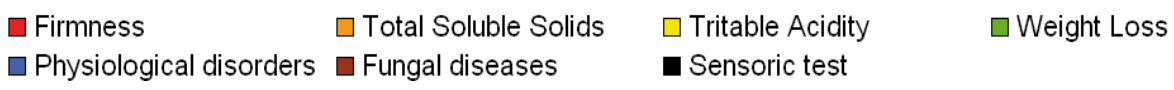

OHD - optimal harvest date

Figure 1. Quality scores of 'Šampion' and 'Royal Gala' fruits after four and six months storage, respectively 
Table 2. CIE $L^{*} a^{*} b^{*}$ colour space of Šampion cultivar at different ripeness stage

\begin{tabular}{|c|c|c|c|c|c|}
\hline \multirow{2}{*}{ No. of measurement } & \multicolumn{5}{|c|}{ Šampion } \\
\hline & $\mathrm{L}^{*}$ & $a^{*}$ & $\mathrm{~b}^{*}$ & $\mathrm{Hue}_{\mathrm{ab}}$ & Chroma \\
\hline & \multicolumn{5}{|c|}{2002} \\
\hline 1 & $64.1 \pm 4.8 \mathrm{ab}^{1}$ & $-15.1 \pm 4.0 \mathrm{a}$ & $40.7 \pm 3.2 \mathrm{abc}$ & $111.7 \pm 5.4 \mathrm{f}$ & $41.2 \pm 2.1 \mathrm{ab}$ \\
\hline 2 & $62.9 \pm 3.5 \mathrm{a}$ & $-12.8 \pm 5.3 a b$ & $38.3 \pm 3.1 \mathrm{a}$ & $108.3 \pm 5.5 \mathrm{ef}$ & $40.5 \pm 3.2 \mathrm{a}$ \\
\hline 3 & $63.9 \pm 3.6 \mathrm{ab}$ & $-12.3 \pm 4.3 \mathrm{ab}$ & $40.0 \pm 2.8 \mathrm{ab}$ & $107.2 \pm 2.8 \mathrm{de}$ & $40.9 \pm 2.9 \mathrm{a}$ \\
\hline 4 & $64.1 \pm 2.8 \mathrm{a}$ & $-10.3 \pm 3.7 b c$ & $39.0 \pm 3.0 \mathrm{ab}$ & $104.6 \pm 4.4 \mathrm{~cd}$ & $40.5 \pm 3.6 \mathrm{a}$ \\
\hline 5 & $64.3 \pm 3.3 \mathrm{ab}$ & $-10.0 \pm 4.9 b c$ & $41.1 \pm 2.9 \mathrm{bcd}$ & $103.7 \pm 3.4 \mathrm{c}$ & $42.3 \pm 2.8 \mathrm{ab}$ \\
\hline $6(\mathrm{OHD})$ & $65.2 \pm 2.1 \mathrm{ab}$ & $-7.3 \pm 3.4 \mathrm{~cd}$ & $40.4 \pm 1.0 \mathrm{abc}$ & $100.1 \pm 2.5 b$ & $41.1 \pm 0.5 \mathrm{ab}$ \\
\hline 7 & $66.9 \pm 1.5 b c$ & $-5.4 \pm 2.8 \mathrm{de}$ & $42.2 \pm 2.0 \mathrm{~cd}$ & $97.2 \pm 1.5 \mathrm{~b}$ & $42.6 \pm 2.1 \mathrm{ab}$ \\
\hline \multirow[t]{2}{*}{8} & $68.3 \pm 1.7 \mathrm{c}$ & $-2.3 \pm 1.5 \mathrm{e}$ & $43.4 \pm 1.4 \mathrm{~d}$ & $93.4 \pm 1.1 \mathrm{a}$ & $43.5 \pm 1.4 b$ \\
\hline & \multicolumn{5}{|c|}{2003} \\
\hline 1 & $65.2 \pm 3.1 \mathrm{ab}$ & $-14.4 \pm 2.1 \mathrm{a}$ & $39.0 \pm 4.3 \mathrm{a}$ & $110.2 \pm 2.4 \mathrm{~d}$ & $41.6 \pm 4.5 \mathrm{a}$ \\
\hline 2 & $63.1 \pm 3.7 \mathrm{a}$ & $-11.5 \pm 4.3 b$ & $38.3 \pm 4.4 \mathrm{a}$ & $106.7 \pm 3.8 \mathrm{c}$ & $40.0 \pm 4.5 \mathrm{a}$ \\
\hline 3 & $64.9 \pm 2.0 \mathrm{ab}$ & $-10.3 \pm 4.3 b$ & $41.2 \pm 2.2 \mathrm{ab}$ & $104.1 \pm 3.8 \mathrm{c}$ & $42.6 \pm 1.8 \mathrm{a}$ \\
\hline 4 (OHD) & $64.1 \pm 2.8 \mathrm{ab}$ & $-7.4 \pm 3.1 \mathrm{c}$ & $39.3 \pm 4.8 \mathrm{ab}$ & $100.5 \pm 3.0 \mathrm{~b}$ & $40.1 \pm 5.0 \mathrm{a}$ \\
\hline 5 & $64.6 \pm 3.3 \mathrm{ab}$ & $-6.2 \pm 4.9 \mathrm{~cd}$ & $40.5 \pm 1.7 \mathrm{ab}$ & $98.6 \pm 4.2 \mathrm{ab}$ & $41.1 \pm 1.9 \mathrm{a}$ \\
\hline 6 & $66.6 \pm 2.1 \mathrm{~b}$ & $-5.8 \pm 1.1 \mathrm{~cd}$ & $41.4 \pm 2.7 \mathrm{ab}$ & $97.9 \pm 2.8 \mathrm{ab}$ & $41.8 \pm 2.8 \mathrm{a}$ \\
\hline \multirow[t]{2}{*}{7} & $66.7 \pm 1.5 b$ & $-4.7 \pm 2.5 \mathrm{~d}$ & $42.5 \pm 2.9 \mathrm{~b}$ & $96.3 \pm 3.3 \mathrm{a}$ & $42.8 \pm 2.8 \mathrm{a}$ \\
\hline & \multicolumn{5}{|c|}{2004} \\
\hline 1 & $62.9 \pm 2.3 \mathrm{ab}$ & $-14.9 \pm 2.0 \mathrm{a}$ & $38.6 \pm 5.0 \mathrm{a}$ & $111.1 \pm 2.8 \mathrm{e}$ & $41.4 \pm 5.0 \mathrm{a}$ \\
\hline 2 & $64.7 \pm 3.0 \mathrm{~b}$ & $-12.5 \pm 3.2 \mathrm{ab}$ & $37.9 \pm 3.9 \mathrm{a}$ & $108.3 \pm 4.8 \mathrm{de}$ & $40.0 \pm 3.9 \mathrm{a}$ \\
\hline 3 & $64.4 \pm 4.0 \mathrm{~b}$ & $-11.6 \pm 3.6 b$ & $40.8 \pm 3.5 \mathrm{ab}$ & $106.0 \pm 5.5 \mathrm{~d}$ & $42.6 \pm 3.1 \mathrm{a}$ \\
\hline 4 (OHD) & $61.1 \pm 2.0 \mathrm{a}$ & $-8.0 \pm 2.9 \mathrm{c}$ & $41.2 \pm 4.4 \mathrm{ab}$ & $100.9 \pm 3.3 \mathrm{c}$ & $42.0 \pm 4.7 \mathrm{a}$ \\
\hline 5 & $63.6 \pm 3.6 \mathrm{ab}$ & $-6.6 \pm 3.9 \mathrm{~cd}$ & $41.2 \pm 2.7 \mathrm{ab}$ & $98.9 \pm 4.9 \mathrm{bc}$ & $41.9 \pm 3.1 \mathrm{a}$ \\
\hline 6 & $65.6 \pm 2.8 b c$ & $-5.2 \pm 2.2 \mathrm{de}$ & $42.2 \pm 2.6 \mathrm{a}$ & $96.9 \pm 2.8 \mathrm{ab}$ & $42.5 \pm 2.7 \mathrm{a}$ \\
\hline \multirow[t]{2}{*}{7} & $67.8 \pm 1.9 \mathrm{c}$ & $-3.2 \pm 1.0 \mathrm{e}$ & $42.6 \pm 1.4 \mathrm{a}$ & $94.3 \pm 1.4 \mathrm{a}$ & $42.7 \pm 1.4 \mathrm{a}$ \\
\hline & \multicolumn{5}{|c|}{2005} \\
\hline 1 & $65.2 \pm 1.8 \mathrm{ab}$ & $-15.1 \pm 2.2 \mathrm{a}$ & $40.8 \pm 1.1 \mathrm{abc}$ & $110.3 \pm 2.7 \mathrm{~d}$ & $43.5 \pm 1.7 b$ \\
\hline 2 & $64.2 \pm 2.7 \mathrm{a}$ & $-12.5 \pm 4.0 \mathrm{~b}$ & $38.1 \pm 3.9 \mathrm{a}$ & $108.0 \pm 5.5 \mathrm{~d}$ & $40.2 \pm 4.0 \mathrm{a}$ \\
\hline 3 & $65.1 \pm 3.0 \mathrm{ab}$ & $-10.2 \pm 4.5 \mathrm{bc}$ & $40.7 \pm 3.4 \mathrm{abc}$ & $104.2 \pm 6.0 \mathrm{c}$ & $42.1 \pm 3.3 \mathrm{ab}$ \\
\hline 4 & $64.5 \pm 1.9 \mathrm{a}$ & $-9.0 \pm 2.2 \mathrm{~cd}$ & $39.3 \pm 2.3 \mathrm{ab}$ & $102.8 \pm 3.5 \mathrm{bc}$ & $40.4 \pm 2.2 \mathrm{a}$ \\
\hline $5(\mathrm{OHD})$ & $66.6 \pm 1.6 \mathrm{bc}$ & $-7.2 \pm 1.3 \mathrm{de}$ & $39.7 \pm 2.3 \mathrm{ab}$ & $100.2 \pm 1.7 \mathrm{~b}$ & $40.3 \pm 2.6 \mathrm{a}$ \\
\hline 6 & $67.9 \pm 1.1 \mathrm{c}$ & $-4.9 \pm 1.0$ ef & $41.2 \pm 2.0 \mathrm{bc}$ & $96.8 \pm 1.4 \mathrm{a}$ & $41.5 \pm 2.2 \mathrm{ab}$ \\
\hline \multirow[t]{2}{*}{7} & $68.5 \pm 1.7 \mathrm{c}$ & $-3.0 \pm 1.5 \mathrm{f}$ & $42.5 \pm 2.9 \mathrm{c}$ & $94.1 \pm 2.2 \mathrm{a}$ & $42.6 \pm 2.3 \mathrm{ab}$ \\
\hline & \multicolumn{5}{|c|}{2006} \\
\hline 1 & $62.7 \pm 2.8 \mathrm{a}$ & $-16.3 \pm 1.9 \mathrm{a}$ & $38.6 \pm 2.4 \mathrm{a}$ & $113.0 \pm 2.9 \mathrm{e}$ & $41.9 \pm 2.3 \mathrm{ab}$ \\
\hline 2 & $62.0 \pm 2.2 \mathrm{a}$ & $-15.9 \pm 1.7 \mathrm{a}$ & $39.2 \pm 2.6 \mathrm{a}$ & $112.0 \pm 2.7 \mathrm{e}$ & $42.3 \pm 2.5 \mathrm{abc}$ \\
\hline 3 & $64.2 \pm 2.0 \mathrm{a}$ & $-13.7 \pm 2.6 b$ & $39.9 \pm 2.5 \mathrm{ab}$ & $109.0 \pm 3.8 \mathrm{~d}$ & $42.2 \pm 2.1 \mathrm{abc}$ \\
\hline 4 & $64.7 \pm 4.6 \mathrm{a}$ & $-11.0 \pm 2.7 c$ & $38.5 \pm 3.4 \mathrm{a}$ & $106.1 \pm 4.7 \mathrm{~cd}$ & $40.2 \pm 1.4 \mathrm{a}$ \\
\hline 5 & $63.1 \pm 2.6 \mathrm{a}$ & $-11.1 \pm 2.5 \mathrm{c}$ & $42.2 \pm 2.7 \mathrm{bc}$ & $104.6 \pm 2.9 \mathrm{c}$ & $43.7 \pm 3.2 b c$ \\
\hline 6 & $65.0 \pm 2.6 \mathrm{a}$ & $-10.1 \pm 3.3 c$ & $43.4 \pm 3.4 \mathrm{c}$ & $103.2 \pm 4.4 \mathrm{bc}$ & $44.7 \pm 3.3 \mathrm{c}$ \\
\hline 7 (OHD) & $64.2 \pm 2.5 \mathrm{a}$ & $-7.8 \pm 2.1 \mathrm{~d}$ & $42.7 \pm 2.8 \mathrm{c}$ & $100.5 \pm 3.0 \mathrm{ab}$ & $43.4 \pm 2.1 \mathrm{bc}$ \\
\hline 8 & $68.2 \pm 2.9 \mathrm{a}$ & $-6.3 \pm 2.1 \mathrm{~d}$ & $43.7 \pm 1.6 \mathrm{c}$ & $98.2 \pm 2.7 \mathrm{a}$ & $44.2 \pm 1.8 \mathrm{bc}$ \\
\hline
\end{tabular}

${ }^{1}$ Values marked with the same letters do not differ significantly at $\mathrm{p}=0.05$. Values are means $\pm \mathrm{SD},(\mathrm{n}=60)$

$\mathrm{OHD}$ - dates of optimum harvest dates based on evaluation after storage 
Table 3. CIE $\mathrm{L}^{*} \mathrm{a} \mathrm{a}^{*} \mathrm{~b}$ * colour space of 'Royal Gala' cultivar at different ripeness stages

\begin{tabular}{|c|c|c|c|c|c|}
\hline \multirow{2}{*}{ No. of measurement } & \multicolumn{5}{|c|}{ Royal Gala } \\
\hline & $\mathrm{L}^{*}$ & $a^{*}$ & $\mathrm{~b}^{*}$ & $\mathrm{Hue}_{\mathrm{ab}}$ & Chroma \\
\hline & \multicolumn{5}{|c|}{2002} \\
\hline 1 & $70.6 \pm 2.1 b^{1}$ & $-13.2 \pm 2.2 \mathrm{a}$ & $35.7 \pm 1.8 \mathrm{~d}$ & $110.3 \pm 3.2 \mathrm{de}$ & $38.1 \pm 2.1 \mathrm{c}$ \\
\hline 2 & $65.4 \pm 3.0 \mathrm{a}$ & $-12.3 \pm 2.4 \mathrm{a}$ & $30.7 \pm 2.6 b c$ & $112.0 \pm 5.5 \mathrm{e}$ & $33.2 \pm 1.7 \mathrm{~b}$ \\
\hline 3 & $65.1 \pm 1.9 \mathrm{a}$ & $-7.9 \pm 3.0 \mathrm{~b}$ & $27.8 \pm 3.3 \mathrm{a}$ & $106.1 \pm 6.2 \mathrm{~d}$ & $29.0 \pm 3.1 \mathrm{a}$ \\
\hline 4 & $65.4 \pm 4.0 \mathrm{a}$ & $-7.0 \pm 3.6 b c$ & $35.3 \pm 3.4 \mathrm{~d}$ & $101.1 \pm 5.3 \mathrm{c}$ & $36.1 \pm 4.1 \mathrm{c}$ \\
\hline 5 & $67.6 \pm 5.3 \mathrm{ab}$ & $-5.1 \pm 3.7 \mathrm{~cd}$ & $31.8 \pm 3.0 \mathrm{c}$ & $98.8 \pm 5.8 \mathrm{bc}$ & $32.3 \pm 3.0 \mathrm{~b}$ \\
\hline $6(\mathrm{OHD})$ & $67.5 \pm 2.4 \mathrm{ab}$ & $-3.0 \pm 2.4 \mathrm{de}$ & $28.5 \pm 3.2 \mathrm{ab}$ & $96.4 \pm 5.4 \mathrm{ab}$ & $28.8 \pm 3.1 \mathrm{a}$ \\
\hline 7 & $64.9 \pm 5.7 \mathrm{a}$ & $-2.8 \pm 2.4 \mathrm{de}$ & $29.4 \pm 2.7 \mathrm{abc}$ & $95.2 \pm 4.0 \mathrm{ab}$ & $29.6 \pm 2.8 \mathrm{a}$ \\
\hline \multirow[t]{2}{*}{8} & $66.3 \pm 4.6 \mathrm{a}$ & $-1.3 \pm 1.7 \mathrm{e}$ & $28.0 \pm 3.2 \mathrm{ab}$ & $92.8 \pm 3.4 \mathrm{a}$ & $28.0 \pm 3.1 \mathrm{a}$ \\
\hline & \multicolumn{5}{|c|}{2003} \\
\hline 1 & $69.5 \pm 2.9 \mathrm{~b}$ & $-9.5 \pm 2.6 \mathrm{a}$ & $30.5 \pm 2.9 \mathrm{ab}$ & $107.1 \pm 3.1 \mathrm{c}$ & $31.9 \pm 3.7 \mathrm{bc}$ \\
\hline 2 & $65.0 \pm 3.1 \mathrm{a}$ & $-9.8 \pm 2.6 \mathrm{a}$ & $32.0 \pm 2.6 \mathrm{~b}$ & $106.9 \pm 4.2 \mathrm{c}$ & $33.5 \pm 2.5 \mathrm{c}$ \\
\hline 3 & $70.6 \pm 3.3 b$ & $-8.8 \pm 1.7 \mathrm{a}$ & $31.4 \pm 3.0 \mathrm{~b}$ & $105.7 \pm 3.4 \mathrm{c}$ & $32.7 \pm 3.2 \mathrm{bc}$ \\
\hline 4 & $69.7 \pm 2.1 \mathrm{~b}$ & $-7.8 \pm 2.5 \mathrm{a}$ & $32.3 \pm 2.5 \mathrm{~b}$ & $103.7 \pm 4.8 \mathrm{c}$ & $33.3 \pm 2.2 \mathrm{c}$ \\
\hline 5 (OHD) & $65.7 \pm 2.2 \mathrm{a}$ & $-4.9 \pm 1.2 b$ & $32.1 \pm 3.7 \mathrm{~b}$ & $98.9 \pm 2.5 b$ & $32.5 \pm 2.2 \mathrm{bc}$ \\
\hline 6 & $66.4 \pm 1.9 \mathrm{a}$ & $-3.6 \pm 1.6 b c$ & $29.4 \pm 4.6 \mathrm{ab}$ & $96.9 \pm 2.7 \mathrm{ab}$ & $29.7 \pm 4.9 \mathrm{ab}$ \\
\hline 7 & $64.7 \pm 3.1 \mathrm{a}$ & $-3.3 \pm 2.0 b c$ & $30.7 \pm 2.9 \mathrm{ab}$ & $96.9 \pm 3.5 \mathrm{ab}$ & $30.9 \pm 2.6 \mathrm{abc}$ \\
\hline \multirow[t]{2}{*}{8} & $64.8 \pm 3.6 \mathrm{a}$ & $-2.1 \pm 1.1 \mathrm{c}$ & $27.7 \pm 4.2 \mathrm{a}$ & $93.7 \pm 3.6 \mathrm{a}$ & $27.8 \pm 3.4 \mathrm{a}$ \\
\hline & \multicolumn{5}{|c|}{2004} \\
\hline 1 & $68.1 \pm 2.5 \mathrm{bc}$ & $-13.2 \pm 2.2 \mathrm{a}$ & $35.1 \pm 2.3 \mathrm{~d}$ & $110.7 \pm 4.3 \mathrm{e}$ & $37.5 \pm 1.6 \mathrm{~d}$ \\
\hline 2 & $64.9 \pm 4.1 \mathrm{abc}$ & $-9.2 \pm 2.8 b$ & $32.5 \pm 3.6 \mathrm{~cd}$ & $105.9 \pm 5.4 \mathrm{~d}$ & $33.9 \pm 3.5 \mathrm{bc}$ \\
\hline 3 & $61.9 \pm 2.9 \mathrm{a}$ & $-7.9 \pm 2.1 b$ & $35.7 \pm 3.9 \mathrm{~d}$ & $102.5 \pm 3.2 \mathrm{~cd}$ & $36.6 \pm 2.7 \mathrm{~cd}$ \\
\hline 4 & $65.5 \pm 3.4 \mathrm{bc}$ & $-5.6 \pm 2.5 \mathrm{c}$ & $30.4 \pm 5.1 \mathrm{bc}$ & $100.4 \pm 4.0 \mathrm{bc}$ & $31.0 \pm 5.7 \mathrm{~b}$ \\
\hline 5 & $68.1 \pm 5.0 \mathrm{c}$ & $-4.5 \pm 2.1 \mathrm{~cd}$ & $30.7 \pm 2.5 \mathrm{c}$ & $98.3 \pm 3.8 \mathrm{~b}$ & $31.1 \pm 2.9 \mathrm{~b}$ \\
\hline 6 & $67.0 \pm 3.3 \mathrm{bc}$ & $-3.5 \pm 2.2 \mathrm{~d}$ & $27.0 \pm 4.0 \mathrm{ab}$ & $97.6 \pm 4.6 \mathrm{~b}$ & $27.3 \pm 4.2 \mathrm{a}$ \\
\hline 7 (OHD) & $66.4 \pm 2.9 \mathrm{bc}$ & $-3.1 \pm 2.0 \mathrm{~d}$ & $26.4 \pm 3.9 \mathrm{a}$ & $97.3 \pm 5.1 \mathrm{~b}$ & $26.6 \pm 4.1 \mathrm{a}$ \\
\hline \multirow[t]{2}{*}{8} & $64.5 \pm 3.4 \mathrm{ab}$ & $-0.8 \pm 0.6 \mathrm{e}$ & $25.4 \pm 4.9 \mathrm{a}$ & $91.1 \pm 2.1 \mathrm{a}$ & $25.4 \pm 5.1 \mathrm{a}$ \\
\hline & \multicolumn{5}{|c|}{2005} \\
\hline 1 & $71.2 \pm 1.7 \mathrm{~d}$ & $-11.2 \pm 1.5 \mathrm{a}$ & $33.1 \pm 2.7 \mathrm{c}$ & $108.8 \pm 3.0 \mathrm{c}$ & $35.0 \pm 2.6 \mathrm{~b}$ \\
\hline 2 & $70.8 \pm 2.1 \mathrm{~d}$ & $-10.3 \pm 1.8 \mathrm{ab}$ & $31.6 \pm 3.5 \mathrm{c}$ & $108.1 \pm 2.6 \mathrm{c}$ & $33.3 \pm 3.6 \mathrm{~b}$ \\
\hline 3 & $66.9 \pm 2.5 \mathrm{abc}$ & $-9.2 \pm 1.5 b$ & $30.8 \pm 2.2 \mathrm{bc}$ & $106.5 \pm 2.2 \mathrm{c}$ & $32.2 \pm 2.3 b$ \\
\hline 4 & $69.7 \pm 2.3 \mathrm{~cd}$ & $-6.5 \pm 2.1 c$ & $32.4 \pm 2.1 \mathrm{c}$ & $101.5 \pm 4.3 b$ & $33.1 \pm 1.8 \mathrm{~b}$ \\
\hline 5 & $68.5 \pm 2.1 \mathrm{bcd}$ & $-6.6 \pm 1.9 c$ & $33.6 \pm 2.9 \mathrm{c}$ & $101.3 \pm 3.8 \mathrm{~b}$ & $34.3 \pm 2.8 \mathrm{~b}$ \\
\hline 6 & $66.7 \pm 3.4 \mathrm{abc}$ & $-5.3 \pm 2.1 \mathrm{~cd}$ & $32.8 \pm 2.1 \mathrm{c}$ & $99.4 \pm 4.1 \mathrm{ab}$ & $33.3 \pm 1.9 \mathrm{~b}$ \\
\hline 7 (OHD) & $67.1 \pm 3.7 \mathrm{abc}$ & $-3.6 \pm 1.9 \mathrm{~d}$ & $28.2 \pm 2.3 \mathrm{ab}$ & $97.7 \pm 4.2 \mathrm{a}$ & $28.6 \pm 2.4 \mathrm{a}$ \\
\hline \multirow[t]{2}{*}{8} & $65.1 \pm 4.8 \mathrm{a}$ & $-2.4 \pm 2.1 \mathrm{~d}$ & $27.4 \pm 3.0 \mathrm{a}$ & $97.2 \pm 4.5 \mathrm{a}$ & $27.7 \pm 2.6 \mathrm{a}$ \\
\hline & \multicolumn{5}{|c|}{2006} \\
\hline 1 & $71.3 \pm 2.2 \mathrm{~d}$ & $-10.6 \pm 2.1 \mathrm{a}$ & $32.3 \pm 2.7 \mathrm{ab}$ & $108.2 \pm 3.8 \mathrm{~d}$ & $34.0 \pm 2.5 \mathrm{c}$ \\
\hline 2 & $66.9 \pm 2.4 \mathrm{bc}$ & $-8.8 \pm 3.0 \mathrm{ab}$ & $32.9 \pm 2.9 \mathrm{~b}$ & $104.9 \pm 5.1 \mathrm{~cd}$ & $34.2 \pm 2.7 \mathrm{c}$ \\
\hline 3 & $61.9 \pm 3.2 \mathrm{a}$ & $-7.5 \pm 2.4 b c$ & $29.7 \pm 4.2 \mathrm{ab}$ & $104.5 \pm 5.1 \mathrm{~cd}$ & $30.7 \pm 4.1 \mathrm{ab}$ \\
\hline 4 & $68.7 \pm 4.7 \mathrm{~cd}$ & $-7.1 \pm 2.3 b c$ & $29.0 \pm 3.2 \mathrm{a}$ & $104.1 \pm 5.1 \mathrm{~cd}$ & $29.9 \pm 2.3 \mathrm{a}$ \\
\hline 5 & $65.7 \pm 3.9 \mathrm{bc}$ & $-6.4 \pm 2.6 c$ & $33.0 \pm 3.4 \mathrm{~b}$ & $101.0 \pm 4.7 \mathrm{bc}$ & $33.7 \pm 3.8 \mathrm{bc}$ \\
\hline $6(\mathrm{OHD})$ & $67.4 \pm 2.2 \mathrm{bc}$ & $-4.0 \pm 2.4 \mathrm{~d}$ & $31.3 \pm 3.5 \mathrm{ab}$ & $97.2 \pm 4.3 \mathrm{ab}$ & $31.7 \pm 4.0 \mathrm{abc}$ \\
\hline 7 & $64.6 \pm 4.6 \mathrm{ab}$ & $-2.0 \pm 0.9 \mathrm{~d}$ & $30.3 \pm 4.1 \mathrm{ab}$ & $93.9 \pm 1.7 \mathrm{a}$ & $30.3 \pm 4.4 \mathrm{a}$ \\
\hline
\end{tabular}

${ }^{1}$ Explanations: see Table 2 
The highest firmness was obtained for fruits picked on the first and/or second harvest date. The firmness of 'Royal Gala' apples was higher after storage, and there were fewer differences between the firmness values of fruits from different harvest dates, with no significant differences in three out of the five years of research. In this cultivar, therefore, the firmness had less of an effect on the final result.

Similar observations were made for the TSS value, i.e. it differed depending on the harvest date and significantly affected the final score mainly in the case of 'Šampion'. The loss of fruit mass due to transpiration and respiration substantially influenced the final score of both cultivars. Except in 2003, the loss of fruit mass was different for all harvest dates of 'Šampion'. Fruits harvested on the earliest date showed the greatest mass loss, and therefore received the lowest final scores. An increased mass loss was observed in fruits collected after the OHD only in the years 2005 and 2006. The year 2004 was exceptional in that the least mass loss was observed for 'Šampion' fruits harvested on the earliest date. The incidence of physiological disorders affected the storability of fruits from the respective harvest dates in both cultivars each year, and therefore had a strong impact on their final scores. The incidence of fungal diseases in fruits from different harvest dates was of somewhat lesser relevance for storability. All of the analysed CIE L* $a^{*} b *$ parameters illustrating the changes in the skin base colour showed similar changes in the individual years. The $\mathrm{L}^{*}$ coordinate (representing lightness) and the $b^{*}$ coordinate (representing the colours from blue to yellow) did not prove crucial in illustrating the base colour changes (Tabs 2 and 3). Both in the case of 'Šampion' and 'Royal Gala' there were years in which no statistical differences were found or differences seemed to be random. The changes in fruit colour were best reflected by the $a^{*}$ coordinate representing the colours from dark green to magenta. The coordinate assumed the values from below minus ten to around zero, and ranged between -7.2 and -8.0 for 'Šampion' and between -3.0 and -4.9 for 'Royal Gala' during the optimum harvest period. The change in the $b^{*}$ coordinate was less distinct, but a growing tendency for the 'Šampion' fruits and a falling tendency for the 'Royal Gala' fruits could be observed with the consecutive harvest dates. In addition, the $\mathrm{Hue}_{\mathrm{ab}}$ value reflected the colour changes very clearly. Its range was much larger than that of the above coordinates, with the values between 100 and 101 at the OHD of 'Šampion' and between 96 and 99 at the OHD of 'Royal Gala'. No consistent patterns in the chroma value were observed depending on the harvest date.

\section{DISCUSSION}

The variation of scores between individual harvest dates obtained for 'Royal Gala' is smaller than that obtained for 'Šampion', which may imply a longer optimum harvest period for 'Royal Gala'. This conclusion can also be drawn from the many years of research by Peris et al. (2005), which shows that the 'Royal Gala' apples are characterised by a low variability of fruit maturity. Base colour changes began very early, i.e. they could be observed already at the beginning of the measurement period (in some cases 30 days before OHD) and the course of changes was similar for each year, so the optimum harvest date could be predicted very early for both varieties. The popular method based on starch changes measured by starch pattern index starts later than the beginning of colour changes, usually 15-20 days before OHD (Brookfield et al. 1997), so colour changes can be an earlier indicator for 'Šampion' and 'Royal Gala'. The value of $a^{*}$ has been suggested as the primary coordinate of change near harvest for peaches (Delwiche and Baumgartner 1983) and has been described as a very good colour index of maturity (Delwiche and Baumgartner 1985, Corey and Schlimme 1988, Ferrer et al. 2005). Changes from a green colour to more yellowish coloured skin are the result of chlorophyll degradation in most fruits and vegetables. In most works, except Ferrer et al. (2005), the Hue ${ }_{a b}$ value is not reported to be a good maturity index. However, the results obtained in this study show that it decreased linearly with time and that it correlated well with all parameters related to maturity, especially for 'Šampion'. 'Šampion' apples, for which the precise determination of colour changes is crucial for long storage (Łysiak 2011), have a very repeatable curve of colour changes every year. Both the measurement of the $\mathrm{a}^{*}$ coordinate and the $\mathrm{Hue}_{\mathrm{ab}}$ angle can provide a basis for determining the harvest date. The $\mathrm{L}^{*}$ and $b^{*}$ values are worse indicators and only the trend of $b^{*}$ can provide some clue as to the harvest date. 'Royal Gala' shows a much greater variability of CIE $L^{*} a^{*} b^{*}$ values. It is also more difficult to determine its optimum harvest date based on the evaluation after storage. This is probably caused by a longer optimum harvest period for this cultivar, and a naturally high variance of measured samples of 'Gala' apples (Lin and Walsh 2008). The greater variability of results obtained for 'Royal Gala' may 
be also due to the measurement difficulties resulting from a relatively intensive blush. Sometimes the blush covers almost the entire fruit and therefore it is difficult to find spots with the pure base colour or measurement errors are made due to overlapping pigments. 'Royal Gala', like 'Elstar', is a cultivar that has a weak correlation between consumer acceptance and instrumental values with the exception of measurements of firmness (Hoehn et al. 2003), therefore it is more difficult to determine its $\mathrm{OHD}$ and a high variation in the results was observed.

\section{CONCLUSIONS}

1. The measurement of $\mathrm{a}^{*}$ and calculation of $\mathrm{Hue}_{\mathrm{ab}}$ can be a good ripening indicator. The optimum $a^{*}$ value for apple harvest is between -7.2 and -8.0 for 'Šampion' and between -3.0 and -4.9 for 'Royal Gala', whereas Hue ab $_{\text {is }}$ 100-101 for 'Šampion' and 96-99 for 'Royal Gala'.

2. The optimum harvest date for Šampion' and 'Royal Gala' apples intended for long storage can vary by over two weeks in the Greater Poland region (Poland).

\section{REFERENCES}

ANONIM, 1986. Insight in color. CIE L*, $\mathrm{a}^{*}, \mathrm{~b}^{*}$ color space 1986. HunterLab, Applications Note 8(7). Available online at http://www.hunterlab.com/ appnotes/an07_96a.pdf; cited on 21 Feb 2012.

Carreño J., Martinez A., Almela L., Fernandez-López J.A., 1995. Proposal of an index for the objective evaluation of colour of red table grapes. Food Res. Intl. 28(4): 373-377.

Brookfield P., Murphy P., Harker R., Macrae E., 1997. Starch degradation and starch pattern indices; interpretation and relationship to maturity. Postharv. Biol. Technol. 11: 23-30.

Corey K.A., Schlimme D.V., 1988. Relationship of rind gloss and groups of colour to flesh quality of watermelon fruits during maturation. Sci. Hort. 34: 211-218.

Delwiche M.J., Baumgartner R.A., 1983. Ground color measurements of peach. J. Am. Soc. Hort. Sci. 108(6): 1012-1016.

Delwiche M.J., Baumgartner R.A., 1985. Ground color as a peach maturity index. J. Amer. Soc. Hort. Sci. 110(6): 53-57.

Ferer A., Remon S., Negueruela A.I., 2005. Changes during ripening of the very late season Spanish peach cultivar Calanda Feasibility of using CIELab coordinates as maturity indices. Sci. Hort. 105: 435-446.
FRANCIS F.J., 1980. The quality evaluation of horticultural crops. HortSci. 15: 58-59.

Gonçalves B., Silva A.P., Moutinho-Pereira J., Bacelar E., Rosa E.M., Meyer A.S., 2007. Effect of ripeness and postharvest storage on the evolution of colour and anthocyannis in cherries (Prunus avium L.). Food Chem. 103: 976-984.

Goupy P., Amiot M.J., Richard-Forget F., Duprat F., Aubert S., Nicolas J., 1995. Enzymatic browning of model solutions and apple phenolic substrates by apple polyphenoloxidase. J. Food Sci. 60(3): 497-501.

Hoenn E., Gasser F., Guggenbuhl B., Kunsch U., 2003. Efficacy of instrumental measurements for determination of minimum requirements of firmness, soluble solids and acidity of several apple varieties in comparison to consumer expectations. Postharv. Biol. Technol. 27: 27-37.

KADER A.A., 1999. Fruit maturity, ripening, and quality relationships. Acta Hort. 485: 203-208.

Kang S.P., East A.R., Trujillo F.J., 2008. Colour vision system evaluation of bicolour fruit: A case study with 'B74' mango. Postharv. Biol. Technol. 49: 77-85.

Kays S.J., 1991. Postharvest physiology of perishable plant products. Van Nostrand Reinhold, New York.

Konopacka D., PŁocharski W., Zwierz J., 2003. Perception of apple quality in relation to texture attributes. Acta Hort. 604: 443-448.

Lin S., Walsh C.S., 2008. Studies of "tree factor" and its role in the maturation and ripening of 'Gala' and 'Fuji' apples. Postharv. Biol. Technol. 48: 99-106.

LuChsinger L.E., Walsh C.S., 1998. Development of an objective and non-destructive harvest maturity index for peaches and nectarines. Acta Hort. 465: 679-688.

Łysiak G.P., KuRlus R., 2000. Rootstock effect on optimum harvest date and storability of two apple cultivars. Proc. Int. Conf. Fruit Production and Fruit Breeding, 12-13 September, Tartu, Estonia: 72-75.

ŁYSIAK G., 2011. The determination of harvest index of Šampion apples intended for long storage. Acta Sci. Pol. - Hortorum Cultus 10(3): 273-282.

Mclellan M.R., Lind L.R., Kime R.W., 1995. Hue angle determinations and statistical analysis for multiquadrant Hunter L, a, b data. J. Food Quality 18: 235-240.

Meredith F.I., Robertson J.A., Horvat R.J., 1989. Changes in ethylene rate and ground color in peaches (cv. Redhavesn and Marqueen) and nectarines (cv. Fantasia) during maturation and ripening. J. Agric. Food Chem. 37(5): 1210-1214.

Peirs A., Schenk A., Nicolai B.M., 2005. Effect of natural variability among apples on the accuracy of VIS-NIR calibration models for optimal harvest date predictions. Postharv. Biol. Technol. 35: 1-13.

PN-90-A-75101/04, 1990. Przetwory owocowe i warzywne. Przygotowanie próbek i metody badań fizykochemicznych. Oznaczanie kwasowości ogólnej. [Fruit and vegetable products. Preparations of 
samples and methods of investigating chemical and physical properties. Marking general acidness] (in Polish).

\section{OCENA PRZYDATNOŚĆI BARWY \\ PODSTAWOWEJ SKÓRKI JAKO WSKAŹNIKA WYZNACZANIA DOJRZAŁOŚCI ZBIORCZEJ DWÓCH ODMIAN JABŁEK (MALUS DOMESTICA BORKH.)}

Streszczenie: System pomiaru barw CIE L* a* $\mathrm{b}^{*}$ jest stosowany do oceny barwy żywności. Zaletą jego stosowania przy pomiarze barwy zasadniczej jabłek jest możliwość pomiaru barwy tego samego owocu, zarówno przed, jak i w czasie osiagania przez niego fazy dojrzałości zbiorczej. Celem badań przeprowadzonych w latach 2002-2006 była ocena szybkiej i niedestrukcyjnej metody wyznaczania dojrzałości zbiorczej jabłek przeznaczonych do długiego przechowywania, opartej na śledzeniu zmian barwy podstawowej skórki. Ponadto, istotne było porównanie tej metody $\mathrm{z}$ innymi metodami bądź wskaźnikami służącymi do wyznaczania terminu zbioru. Pomiary barw prowadzono dla dwóch odmian jabłoni Šampion i Royal Gala i miały między innym służyć do stworzenia wzorców dla tych odmian dla praktycznego ich zastosowania w sadzie. Spośród ocenianych wskaźników barw L*, $a^{*}, b^{*}$, kat Hue $_{a b}$, chroma, zmiany barwy zasadniczej najlepiej obrazowały wartości koordynaty a* oraz wartość kąta Hue ${ }_{a b}$. Ocena jakości owoców po przechowywaniu pozwoliła na stwierdzenie, że ich jakość była najlepsza wtedy, gdy w okresie zbioru koordynata $\mathrm{a}^{*}$ zawierała się $\mathrm{w}$ przedziale pomiędzy -7 i -8 dla owoców odmiany Šampion oraz pomiędzy -3 i -5 dla owoców odmiany Royal Gala. Wartość kąta Hue ${ }_{a b}$ w okresie optymalnego terminu zbioru wynosiła pomiędzy 100 i 101 dla 'Šampiona' i 96-99 dla 'Royal Gala'. Pomiar koordynaty barwy a* oraz kata Hue ${ }_{a b}$ może być zatem dobrym wyznacznikiem dojrzałości zbiorczej.

Received September 5, 2011; accepted May 10, 2012 